\title{
The effects of communication between student athletes and physical education teachers on competition success and motivation
}

\author{
Mehmet Veysi Bora ${ }^{1 \mathrm{a}}$, and Recep Cengiz ${ }^{2}$ \\ ${ }^{1}$ Physical Education Teacher, Mardin/Turkey \\ ${ }^{2}$ Bartın University, Physical Education and Sport College, Bartın/Turkey
}

\begin{abstract}
Absctract.This research aimed to explore the effects of communication between student athletes and physical education teachers on competition success and motivation using the parameters such as sport branch, sex, age, and some other variables. The sample group was composed of 631 student athletes (471 male and 160 female) attending to secondary schools in Mardin. In order to gather data, "Success Motivation in Sport" Questionnaire developed by Tiryaki and Gödelek (1997), and "Trainers Communication Scale" developed by Abakay and Kuru (2009) were adapted to the students. In order to test data distribution, KolmogorovSimirnov test was used. As the data showed a normal distribution according to the ages and service period of the teachers $(p=.000<\alpha=0,05)$, parametric tests were used for data evaluation. In order to analyze the data, arithmetic averages, One-Way ANOVA, Independent samples t-test were used, and Tukey HSD was used to find out the main reason causing the difference between two variables.As a result, it was found out that the communication skills of the teachers had positive effects on the strength demonstration and gaining success motives of the student athletes. Moreover, students playing Basketball showed a higher degree of perception on this issue when compared to the students attending other sports.
\end{abstract}

Keywords: Physical Education Teacher, Communication, Competition Success, Motivation

\section{Introduction}

Communication, our individual and social life is a phenomenon which covers every moment. People for better understand and recognize each other and problems of jobs in an organization to better resolved, they need a healthy communication. Effective communication skills, as each individual's private life also learning process, is basic skills

\footnotetext{
${ }^{a}$ Corresponding author: mehmetveysibora@hotmail.com
} 
needed to deal with the self-expression and social environment [5]. Communication skills is includes skills such as starting skills (communication starting, maintaining, termination and listening), self-expression (encouragement, asking for help, giving instructions, to express feelings, to complain, to convince) and responsiveness ( response to compliments, apologies, complaints and responding to anger) [6]. Effective communication skills can facilitate relationships in the all kinds of human relations and all kinds of professional field. For example, If communication messages not understand in the process of classroom management for physical education teachers, occurred problems in training and lesson not be able to find solutions and not get to know. Bodily awareness which can be provided with sports activities, may also be effective in the use of body language consciously [3]. In this regard, school environment is important element because people come together to learn needs for his people 's social life, skills and attitudes through communication [16], [2, 8,]. In this environment, when considered students' goals and expectations, priorities, values and management techniques, the creation of a working environment is important to motivation. Some research claim that student achievement directly related to teacher' skills in the classroom, in the same way it is important for the team to communicate effectively when considered effectively to be working after coach winning the athletes respect and trust [4], [14, 19, 12, 7]. Student-athletes to participate in the high density program and continue for a long time; for explain that the power put forward to one of the theory is success in motivation theory. Success motivation theory explain that why people participate in physical activity cause, why it is difficult to achieve so much effort and explains why it continues for a long time In this process, motivation generally, the individual represents the forces that act towards a particular behavior [1].

Research on motivation of success suggesting many factors affect the motivation of success, like approaching the success, avoiding failures, power display, punishments and rewards, management style [10], [13]. It is very important in terms of performance, physical education teachers have adequate knowledge of students personality, family structure, sports orientation causes, lifestyle issues and methods of motivation [10].

Studies on communications give important clues about physical education teacher's message give to students, the approach to events, leadership qualities, and they reflect the understanding of classroom lessons also their communication skills [18], [11, 25]. However, It is not known enough that what extent students develop their communication skills and what extent students show success in sports competitions. In accordance with the above objectives not only relevant requirements of course and training but also educational attitudes will contribure reconstruction to generate data, is needed a study to demonstrate about physical education teachers and studenst's capabilities of communication.

This research aimed to explore the effects of communication between student athletes and physical education teachers on competition success and motivation using the parameters such as sport branch, sex, age, and some other variables. For this purpose, we search response the following hypothesis :

H1: Is there any significant relationship between students who engaged in sports communication scores in terms of gender?

H2: Does the change students comunication scores according to the sport branch variable?

H3: Does the change students Competition Related Motive Scale score avareges according to sport years?

\section{Method}

The study utilized a quantitative research design. General survey model studies the whole universe or a sample of the universe in order to have a general conclusion about the 
universe consisting of many elements and aims to identify the relationships between variables in the study and the current study utilized relational screening model which is one of the general survey models [15].

The universe of this research center has created Mardin students studying in secondary schools. According to Mardin provincial education directorate; the population of the research 5443 male students and 3685 female studensts who continue secondary schools in Mardin, the sample group was composed of 631 student athletes (471 male and 160 female) attending to secondary schools in Mardin. Planned over 1,000 students, but some students come to school during the application, the reluctance to participate in the study, incomplete or incorrect filling surveys and so on. reasons remained outside the 369 student applications. Following the appointments made with the participants, the data were collected by the researchers via one-on-one interviews that included explanations about the study. In order to determine the sample size, a random number of primary school were taken into consideration and the sample was generated based on the numbers that composed the universe [15].

Table 1. Frequencies and percentage values based on students personal information

\begin{tabular}{lccc}
\hline Variables & & f & \% \\
\hline \multirow{3}{*}{ Gender } & Female & 160 & 25,4 \\
& Male & 471 & 74,6 \\
& Total & 631 & 100 \\
& Athletics & 25 & 4,0 \\
& Football & 306 & 48,5 \\
Sport Branch & Basketball & 121 & 19,2 \\
& Voleyball & 101 & 16,0 \\
& Other & 78 & 12,4 \\
& Total & 631 & 100 \\
Sport Years & $0-1$ year & 118 & 18,7 \\
& $2-3$ year & 159 & 25,2 \\
& 4 yil + & 354 & 56,1 \\
& Total & 631 & 100 \\
Year of Trainer with Coach & $0-1$ Year & 379 & 60,1 \\
& $2-3$ year & 177 & 28,1 \\
& 4 year + & 75 & 11,8 \\
& Total & 631 & 100 \\
\hline
\end{tabular}

Referring to Table 1.160 of the students (25.4\%) were female and 471 ( $74.6 \%)$ is seen as the male students . Participants 306 students ( $48.5 \%$ ) is located in the football. All Of 354 students ( $56.1 \%$ ) over 4 years and 379 of his active sports ( 60.1 ), it is understood that at least 1 year on a regular basis have the opportunity to trainer with a coach.

\subsection{Measures}

Willis Success Motivation in Sport (SMS): This scale was designed to measure sport specific achievement motives (Motive to Achieve Success, MAS and Motive to Avoid Failure, MAF) and power motive (Pow) [17]. SMS has 40 items. Items were generated which attempt to tap the power motive (Pow) and two achievement-related motives: the 
motive to achieve success (MAS) and the motive to avoid failure (MAF). In the SMS, Pow represented with 12 items (e.g. I try to get other players to train hard), MAS represented with 17 items (e.g. I seem to play better when spectators are present), and MAF represented with 11 items (It is hard for me to stay calm before a game). Alpha and test-retest reliabilities were computed for each of the three scales. It has alpha reliability and test-re test reliability coefficient of .76 and .75 for Pow, .78 and .69 for MAS and .76 an.71 for MAF, respectively. Tiryaki and Gödelek (1997) proved reliability of the WCMRS for Turkish population. It has alpha reliability coefficient of .81 for Pow, .82 for MAS and .80 for MAF for Turkish population.Other scale on our research is Trainer Communication Scale (TCS) with 28 items which developed by Abakay and Kuru (2009). Scale items grade 1-5. Scale all items is positive which "never, rarely, sometimes, frequently, and always". 28 is least point to get from scale and 140 is highest point to get from scale [22].

\subsection{Data Analysis}

SPSS 21,0 statistical package program was used in data analysis. Statistical analysis of study data was completed in four phases. First of all, frequencies and mean values were used to determine descriptive participant statistics. Later, One Sample KolmogorovSmirnov Test was used to determine whether data collection tools displayed normal distribution. Test results pointed that sub components had normal distribution $(\mathrm{p}>0,05)$. Independent sample t-test for two variable comparison and one way ANOVA were utilized for more $(\mathrm{p}=0,05)$.

\section{Findings}

In the findings section are presented applied of students, Trainer Communication Scale Success Motivation in Sport Questionnaire, and personal information of the data obtained in the form of statistical techniques resulting. In this section, the students are included in the sample examined evidence relating to personal characteristics, communication, motivation for the success were investigated.

Table 2. Communication scale score distribution by gender of the students.

\begin{tabular}{llccccc}
\hline & Gender & $\mathbf{N}$ & $\bar{X}$ & SS & t & p \\
\hline \multirow{2}{*}{ Communication Scale } & Female & 160 & 106,6312 & 20,564 & \multirow{2}{*}{, 373} & 0,709 \\
& Male & 471 & 105,9448 & 19,967 & & \\
\hline
\end{tabular}

According to Table 2; There were no significanece difference between average of total point of trainer communication scale and gender variable $(t=0,373, p>0.05)$. According to the results communication with trainer male and female students have same attitude and level of perception.

Table 3. Student Comunication Perceptions According to Branch ANOVA

\begin{tabular}{|c|c|c|c|c|c|c|c|}
\hline & $\begin{array}{l}\text { Sum } \\
\text { Squares }\end{array}$ & $\begin{array}{l}\text { Degrees } \\
\text { Freedom }\end{array}$ & of & $\begin{array}{l}\text { Mean } \\
\text { Squares }\end{array}$ & $\mathbf{F}$ & $\mathbf{p}$ & $\begin{array}{l}\text { Meaningful } \\
\text { Difference }\end{array}$ \\
\hline $\begin{array}{l}\text { Inter } \\
\text { Groups }\end{array}$ & 9348,723 & 4 & & 2337,181 & \multirow{3}{*}{$\begin{array}{l}5,96 \\
3\end{array}$} & \multirow{3}{*}{$\begin{array}{l}, 000 \\
*\end{array}$} & \multirow{3}{*}{$\begin{array}{l}\text { Football } \\
\text { Basketball, } \\
\text { Other } \\
\text { Basketball }\end{array}$} \\
\hline In Groups & 245343,362 & 626 & & 391,922 & & & \\
\hline Total & 254692,086 & 630 & & & & & \\
\hline
\end{tabular}


In Table 3, Students communication perception who doing sports, according to branch variable determined whether statistical significances or not. According to the results there were significance difference between average of total point with perception of communication and branch variable $(\mathrm{f}=5.963 ; \mathrm{p}<0,05)$. This significancess which branch originated from so as to determine test of Tukey HSD and between students who play football $(X=104,25)$ and basketball $(X=112,86)$, in favor of basketball. Besides this, there were significance difference between students who doing other sports $(X=100,51)$ and students who playing basketball $(X=112,86)$, in favor of basketball.

Table 4. Success motivation in sports scale according to sports age of participants results of ANOVA

\begin{tabular}{ccccccc}
\hline & Sport Years & $\mathbf{N}$ & $\bar{X}$ & SS & F & p \\
\hline \multirow{3}{*}{ Power motive } & 0-1 year & 118 & 39.00 & 1.41 & & \\
& $2-3$ year & 159 & 39.41 & 5.49 & 1.330 & .342 \\
& 4 year+ & 354 & 40.04 & 4.15 & & \\
\hline \multirow{2}{*}{ Motive to Achieve } & $0-1$ year & 118 & 63.50 & 1.91 & & \\
Success & 2-3 year & 159 & 63.38 & 5.49 & 1.103 & .157 \\
& 4 year+ & 354 & 62.58 & 7.67 & & \\
\hline \multirow{2}{*}{ Motive to Avoid } & 0-1 year & 118 & 33.50 & 2.64 & & \\
Failure & 2-3 year & 159 & 30.87 & 5.67 & 1.140 & .209 \\
& 4 year+ & 354 & 32.50 & 5.51 & & \\
\hline
\end{tabular}

According to Table 4, there isn't a significance difference in all subdimension of $(\mathrm{p}>0.05)$.

\section{Results and Discussion}

In the educational process "teachers proximity" seen as an important variable in education and at the same time it is assumed that the positive behavior of teachers motivate students. Athletes who establish effective communication with coaches high achievement motivation will be able to recognize good this style is considered to be strong in their ability [20], [21].

In table 2, There were no significanece difference between average of total point of trainer communication scale and gender variable. According to the results communication with trainer male and female students have same attitude and level of perception. Saracoglu and friends (2009), as a statistical acoording to sex and university determation has not changed significantly total scores of skills related to communicationmembers of teacher is believed effective teacher-student relationshi in the rules to be limiting of educational institutions [12]. [4] research has examined the communication skills of teachers in terms of different variables, concluded that 4th class faculty of education students' communication skills no significant differences by gender. [24]found no significant difference in the level of communication skills of high school students [23]. [23] studies for youth camp leader candidates. There was no significant difference in terms of level of communication skills by gender. [33] has been determined that there is no difference the work done by the athletes who competing in amateur sports expectations from coach by gender. [7] has found that there is a no significant difference between communication skills and gender in research examined the effect of communication skills of the team and individual athletes. These data are similar to our findings. The literature indicates that the level of communication skills disparities study showed girls and boys during the socialization process is that they behave differently [3], [22, 32, 26, 31].

A significant differences was found between branch independent variable and total 
point average on trainer with students contact perception. (Table 3) A significant differences was found playing basketbol players and other sport players. In literature indicates there is no effect on communication skills at the least athletes is expected to have high communication skills [7], [27, 34]. Because it is know that sport that remove barriers to communication, develop self-confidence, teach life skills and healthy behavior, a positive effect on job performance [34], [27], Although, the data in this study may be related to such as social, cultural and family variables lack of questioned, it is not possible to make a definitive comment. In the narrow space and in the struggle against time of the basketball field, due to a greater solidarity within the team suggest that external messages have an effect on the level of communication.

According to the findings of the study compared to the sport year dimensions and Sport Success Motivation Scale average scores was no significant difference (Table 4). These results athlete students, the communication method of physical education teachers the impression perceived positively. According to [29] research findings were determined that no significant difference between Power motive, Motive to Achieve Success, Motive to Avoid Failure levels. These data are similar to our findings. According to [30] teachers help and positive approach putting students an effective learning environment so raising the confidence, it an important finding in terms of efficiency.

In the literature, success motivation in sport studies differ in terms of gender, indicating that male and female basketball players demonstrated different behaviors [27]. But as a result of this study communication between coaches and players it is not very pronounced, It has emerged. It had shown that perception of communication is not contact communicate with coaches for working time. However, coaches and players who knew each other for a long time assume that communication is higher [35]. In this case, communication between coaches and players level increases, it can be argued that players achievement will be higher. According to [36]. it will reveal serious miscommunication and loss of motivation. In addition, it will affect significantly. In relation to motivational responses in physical education lessons, physical activity will be habit for living [36]. Therefore, we examined only relationship between the subject physical education students in their year, students will have been affected for their lifelong.

In conclusion, Physical education teacher's, who working in secondary school, communication skills posstive impact on athletes student's show strength and approach success in motivation. It is understood that student's who playing basketball perception higher than students who interested other sports. This research are expected to contribute to understand student athletes, effective communication and improve motivation tools for educational instituties, clubs, administrators, teachers and families. On the basis of the findings and research findings results, the following proposals have been developed.

1. It seen that; teacher cmmunication quality with students effect on students sport skills. In future studies, working with different groups and issues of communication may be useful to demonstrate the impact on athletic performance.

2. This study has been working with students who engaged in sports. In new study can be cover all students groups thus it may be useful for put forward to different problems influence and solutions.

3. To cover all teachers in school courses can be arranged for improve their communication skills.

\section{References}

1. Tiryaki, Ş. Spor Psikolojisi, Kavramlar, Kuramlar ve Uygulama. Mersin: Eylül Kitap ve Yayınevi.(2005). 
2. Deniz, İ. İletişim Becerileri Eğitiminin İlköğretim 8.Sınıf Öğrencilerinin İletişim Becerileri Düzeyine Etkisi. Yayınlanmamış Yüksek Lisans Tezi, Gazi Üniversitesi, Eğitim Bilimleri Enstitüsü, Ankara. (2003).

3. Kılcığıl, E. ve diğg. İki Farklı Üniversitenin Beden Eğitimi ve Spor Yüksekokulu Öğrencilerinin İletişim

Becerilerinin Değerlendirilmesi. Spormetre Beden Eğitimi ve Spor Bilimleri Dergisi, 12(1), 19-28. (2009).

4. Acar, V. Öğretmen Adaylarının İletişim Becerileri. Yayınlanmamış Yüksek Lisans Tezi, Mehmet Akif

Ersoy Üniversitesi, Sosyal Bilimler Enstitüsü, Budur. (2009).

5. Uzuntaş, A. Etkili İletişim: Anlatabilmek ve Anlayabilmek. Kastamonu Eğitim Dergisi, 21(1), 11-30. (2013).

6. Alkan, G. Takım Sporlarında Etkili İletişim Ölçeğinin Türk Takım Sporcularına Uyarlanması. Yayınlanmamış Yüksek Lisans Tezi, Mersin Üniversitesi, Sağlık Bilimleri Enstitüsü, Mersin. (2009).

7. Ulukan, H. İletişim Becerilerinin Takım ve Bireysel Sporculara Olan Etkisi. Yayınlanmamış Yüksek Lisans Tezi, Karamanoğlu Mehmet Bey Üniversitesi, Sosyal Bilimler Enstitüsü, Karaman. (2012).

8. Demiray, U. Etkili İletişim (4.Bask1). Ankara: Pegem Akademi. (2011).

9. Öğülmüş, S. Güdüleme (Motivasyon) Kuramları. Ankara Üniversitesi Eğitim Bilimleri Fakültesi

Dersgisi. 2(5), 92-105. (2002).

10. Doğan, O. Spor Psikolojisi (2.Bask1). Adana: Nobel Kitapevi. . (2005).

11. Dörnyei, Z. Teaching and Researching Motivation. Longman: Essex. (2001).

12. Saracaloğlu, A. \& Yenice, S. \& Karasakaloğlu, N. Öğretmen Adaylarının İletişim ve Problem Çözme Becerileri İle Okuma İlgi ve Alışkanlıkları Arasındaki İlişki. Yüzüncü Y1l Üniversitesi Eğitim Fakültesi Dergisi, 6(2), 187-206. (2009).

13. Lazar, J. İletişim Bilimi (1.Baskı). Ankara: Vadi Yayınları. (2001).

14. Bingöl, G. \& Demir, A. Amasya Sağlık Yüksekokulu Öğrencilerinin İletişim Becerileri. Göztepe Tip Dergisi, 26(4), 152-159. (2011).

15. Karasar, N. Bilimsel Araştırma Yöntemi (21.Baskı). Ankara: Nobel Yayın Dağıtım. (2012).

16. Güney, S. Yönetim ve Organizasyon (2.Bask1). Ankara: Nobel Yayınları. (2007).

17. Willis, J. D. Three Scales to Measure Competition-Related Motives in Sports. Journal of Sport Psychology, (4), 338-353. (1982).

18. Güven, Ö. 12-16 Yaş Grubu Sporcuların Müsabaka Motivasyonu ve Antrenör Davranışları Konusunda Karşılaştıkları Bazı Sorunlar. Gazi Beden Eğitimi ve Spor Bilimleri Dergisi, 1(1), .29-40. (1996).

19. Mirzeoğlu, D. \& Çelebi, M. \& Özcan, G. Öğretmenlik Uygulaması Dersinin Beden Eğitimi Öğretmenlik Öğretmen Adaylarının Sınıf İçi Becerilerine Etkisi. 4. Ulusal Beden Eğitimi ve Spor Öğretmenliği Sempozyumu Bildiriler Kitapçığı, 150-162, Bursa. (2005).

20. Engür, M. Elit Sporcularda Başarı Motivasyonunun, Durumluk Kaygı Düzeyleri Üzerindeki Etkisi. Yayınlanmamış Yüksek Lisans Tezi, Ege Üniversitesi, Sağlık Bilimleri Enstitüsü, İzmir. (2002).

21. Özyalvaç, N. T. Ortaöğretim Öğrencilerinin Beden Eğitim Dersine Yönelik Tutumları İle Akademik Başarı Motivasyonlarının İncelenmesi (Konya Anadolu Lisesi Örneği). Yayınlanmamış Yüksek Lisans Tezi, Selçuk Üniversitesi, Sağlık Bilimleri Enstitüsü, Konya. (2010). 
22. Abakay, U. \& Kuru, E. Coach Communication Scale in Football a Study of Validity and Reliability. International Scientific Conference Perspectives in Physical Education and Sport. 9. th Edition, Constanta, 29-31 May. (2009).

23. Kayışoğlu, N. B. \& Doğan, İ. \& Çetin, M. Gençlik Kampı Lider Adaylarının Duygusal Zekâ Düzeyleri ve İletişism Becerilerinin İncelenmesi. Ankara Üniversitesi Spor Bilimleri Fakültesi Dergisi, 12(1), 43-50. (2002).

24. Siyez, D. M. \& Dilek, T. T. Lise Öğrencilerinin Öfke Kontrolü ve İletişim Becerilerinde Çözüm Odaklı Psiko-Eğitim Programının Etkisi. Türk Psikolojik Danışma ve Rehberlik Dergisi, 5(41), 11-22. (2014).

25. İkizler, C. Sporda Başarıyı Etkileyen Psikolojik Faktörler. Ankara: Nobel Yayınevi. (1994).

26. Korkut, F. Yetişkinlere Yönelik İletişim Becerileri Eğitimi, Hacettepe Üniversitesi Eğitim Fakültesi Dergisi, 28, 143-149. (2005).

27. Aktaș ve Ark. Profesyonel Basketbolcularda Spora Özgü Bașarı Motivasyon Düzeyinin Cinsiyetler Açısından Karşılaştırılması. Spormetre Beden Eğitimi ve Spor Bilimleri Dergisi, 4(2), 55-59. (2006).

28. Harminson, R. J. Peak performance in sport: Identifying Ideal Performance States and Developing Athletes Psychological Skills. Sport, Exercise, and Performance Psychology, 1(5), 3-18. (2011).

29. Aktop, A, \& Erman, K.A. Takım Ve Bireysel Sporcuların Başarı Motivasyonu, Benlik Kaygısı ve Sürekli Kaygı Düzeylerinin Karşılaştırılması. 7. Uluslararası Spor bilimleri Kongresi, Antalya. (2002).

30. Yılmaz, İ. \& Çimen, Z. Beden Eğitimi Öğretmen Adaylarının İletişim Beceri Düzeyleri. Ankara Üniversitesi, Journal of Physical Education and Sport Sciences, 10(3), 1-11. (2008).

31. Tepeköylü, Ö. \& Soytürk, M. \& Çamlıyer, H. Beden Eğitimi ve Spor Yüksekokulu Öğrencilerinin İletişim Becerisi Algılarının Bazı Değişkenler Açısından İncelenmesi. Spormetre Beden Eğitimi ve Spor Bilimleri Dergisi, 7(3), 115-124. (2009).

32. Akandere, M. \& Özyalvaç, N. \& Duman, S. Ortaöğretim Öğrencilerinin Beden Eğitimi Derslerine Yönelik Tutumları İle Akademik Başarı Motivasyonlarının İncelenmesi (Konya Anadolu Lisesi örneği). Selçuk Üniversitesi Sosyal Bilimler Enstitüsü Dergisi, 2(2), 1-12. (2010).

33. Güzel, İ. İ. Amatör Sporcuların Antrenörlerinden Beklentileri Üzerine Bir Araştırma. Yayınlanmamış Yüksek Lisans Tezi, Gazi Üniversitesi, Eğitim Bilimleri Enstitüsü, Ankara. (2008).

34. Şahin, N. Elit Düzeyde Takım Sporu ve Bireysel Spor Yapan İki Grubun İletişim Becerilerinin Karşılaştırılması. Spormetre Beden Eğitimi ve Spor Bilimleri Dergisi, 10(1), 13-16. (2012).

35. Gürüz, D. \& Eğinli, A. T. Kişilerarası İletişim, Bilgiler-Etkiler-Engeller. Ankara: Nobel Yayın Dağıtım. (2008).

36. Bauer, J. C. The Effects of Coaching Behaviors on Motivation in Handball Players. Master Thesis, University Maastricht Faculty of Health Sciences. (2009). 